\title{
A jobb pitvari fülcse echokardiográfiás vizsgálata és annak klinikai jelentősége
}

\author{
Nemes Attila dr. - Havasi Kálmán dr. - Sághy László dr. \\ Kohári Mária dr. - Forster Tamás dr. \\ Szegedi Tudományegyetem, Általános Orvostudományi Kar, Szent-Györgyi Albert Klinikai Központ, \\ II. Belgyógyászati Klinika és Kardiológiai Központ, Szeged
}

\begin{abstract}
Pitvarfibrilláció fennállása esetén a thrombusképződés emelkedett rizikója áll fenn, mely a jobb szívfelet is érintheti. A jobb pitvari fülcse nehezen ábrázolható képlet; a jelen összefoglaló célja a rutinban elérhető echokardiográfiás vizsgálómódszerek bemutatása és az ezzel kapcsolatos klinikai adatok ismertetése.
\end{abstract}

Orv Hetil. 2019; 160(12): 443-447.

Kulcsszavak: jobb pitvari fülcse, echokardiográfia

\section{Echocardiographic evaluation of the right atrial appendage and its clinical consequences}

\begin{abstract}
In case of atrial fibrillation, there is a higher risk of thrombus formation, which could affect the right heart as well. Visualization of the right atrial appendage is difficult; the aim of the present review was to demonstrate the role of routine echocardiographic techniques and to show related clinical data.
\end{abstract}

Keywords: right atrial appendage, echocardiography

Nemes A, Havasi K, Sághy L, Kohári M, Forster T. [Echocardiographic evaluation of the right atrial appendage and its clinical consequences]. Orv Hetil. 2019; 160(12): 443-447.

(Beérkezett: 2018. október 22.; elfogadva: 2018. október 31.)

A Szerkesztóség felkérésére készült tanulmány.

\section{Rövidítések}

$\mathrm{BP}=$ bal pitvar $\mathrm{BPF}=$ bal pitvari fülcse $; \mathrm{FAC}=($ fractional area change) a JPF frakcionális area változása a szívciklus során; ICE $=$ (intracardiac echocardiography) intracardialis echokardiográfia; JP = jobb pitvar; JPF = jobb pitvari fülcse; $\mathrm{PF}=$ pitvarfibrilláció; $\mathrm{SEC}=($ spontaneous echo contrast $)$ spontán echókontraszt; $\mathrm{SR}=$ sinusrhythmus; $\mathrm{TDI}=$ (tissue Doppler imaging) szöveti Doppler-echokardiográfia; TEE $=$ (transesophageal echocardiography) transoesophagealis echokardiográfia; TTE $=$ (transthoracic echocardiography) transthoracalis echokardiográfia

\section{A jobb pitvari fülcse}

A jobb pitvari fülcse (JPF) a jobb pitvar (JP) anterior és medialis oldalán helyezkedik el, átfedi az aortagyököt, az aorta ascendenshez képest anterior pozícióban van, és a vizuálisan könnyen felismerhető musculi pectinati alkotja. A JPF bejáratánál egy különösen nagy pectinatus izom helyezkedik el, melyet taenia saggitalisnak hívnak, és képalkotás során vigyázni kell, nehogy thrombusként diagnosztizáljuk [1].

Bár nem valvularis pitvarfibrilláció $(\mathrm{PF})$ esetén a thromboembolia legfóbb forrása a bal pitvari $(\mathrm{BP})$ fülcse (BPF), ilyenkor mindkét pitvart, beleértve a JPF-t is, befolyásolhatja az aritmia [2]. Bár a vizsgálatok legfóbb célja a legtöbbször a JPF-ben fellelhető esetleges thrombus kizárása, ritkán annak megnagyobbodása (aneurizmája) is detektálható [3]. Ma már három echokardiográfiás kapu (transoesophagealis, transthoracalis és intracardialis) során ábrázolhatók a cardialis struktúrák. Sajnos a JPF-vel kapcsolatos irodalom limitált, az elérhetô klinikai adatokat az alábbiakban részletezzük. 


\section{Transoesophagealis echokardiográfia (TEE)}

TEE során a nyelőcsőbe vezetett transzducer segítségével pontos képet kaphatunk olyan cardialis struktúrákról is, melyek transthoracalis echokardiográfiás vizualizálása nem lehetséges. Ilyenkor a szektor csúcsában a BP van, a korszerü transzducerek multiplán ábrázolást tesznek lehetővé. TEE során a JPF bicavalis, a JP hossztengelyi nézetében ábrázolható 90 és 140 fok között [4] (1. ábra). Klinikai vizsgálatok igazolták, hogy a JPF ábrázolása TEE során 1,3-16\%-ban sikertelennek bizonyul [2].

Kétdimenziós TEE-val vizsgálva PF-betegekben a spontán echókontraszt (spontaneous echo contrast, SEC), az üregben észlelhető dinamikus örvénylés és a füstszerü echók összessége, illetve a thrombus előfordulása a JP-ban és a JPF-ben $1-7,5 \%$ és $10-57 \%[5,6]$. PF-betegekben a thrombus gyakrabban fordul elö a BP/ BPF-ben, mint a jobb oldalon, annak előfordulási aránya a JP/JPF-ben más irodalmi adatok alapján $0,4 \%$ és $7,5 \%$ $[2,6,7]$. Amennyiben a JP/JPF-ben is detektálható thrombus, akkor általában a bal oldalon is [6], de ez nem zárja ki a jobb oldalon önállóan kialakuló thrombus lehetőségét [2]. JPF-thrombus megléte esetén a JP-ban SEC is detektálható [2]; a SEC mértéke ismerten a thrombusképződés prediktora [8]. A pulmonalis embolia valószínûsége egy tanulmány szerint 19\%-nak bizonyult nem valvularis permanens PF fennállása esetén [9]. De Divitiis és mtsai szerint a JPF-thrombus lehetőségének kizárása javasolt valamennyi olyan pulmonalis emboliát szenvedett PF-betegben, akinél a mélyvénás thrombosis nem volt igazolható, mivel ilyenkor nagy valószínúséggel a JPF lehet a thrombosis forrása [6]. JPF-thrombus meg- léte esetén irodalmi adatok alapján a JPF frakcionált area változása (fractional area change, FAC), vagyis a szisztoléban és a diasztoléban mért area aránya kevesebb, mint 20\% [10]. A pitvari fülcsékben eltérő arányban képződő thrombus oka teoretikusan azok eltérő anatómiájában és múködésében keresendő [7]. A JPF szélesebb szájadékú, mint a BPF, míg a BPF-area nagyobb, mint a JPF-é. A JPF szélességének az areájához viszonyított aránya azonban kedvezőbb a BPF-éhez képest [8]. Irodalmi adatok szerint PF fennállása esetén a JPF remodellingje nem alakul ki, míg a BPF megnagyobbodása ismert jelenség [8]. Nincs igazolható eltérés a JPF-areában, valamint a JPF-szélesség és a JPF-area arányában PF-s és sinusrhythmusos (SR-os) esetek között. A fentieken túl a thrombusképződés csökkent előfordulását magyarázhatja a JPF falának speciális struktúrája, a pectinatus izmok és az esetleges thrombusok latens migrációjának lehetősége is [8]. Más szerzők a fentiekkel ellentétben a JPF morfológiai és funkcionális eltéréseit detektálták PF fennállása esetén (nagyobb JPF-area, csökkent JPF-frakcionálisarea-változás és ürülési sebességek) [6]. Hasonló változásokat találtak JPF-thrombus fennállása esetén is. A JP/JPF megnagyobbodása és funkcióromlása összefüggést mutat a jobb kamra megnagyobbodásával, funkciójának romlásával és emelkedett pulmonalisartérianyomással [8]. A fentieken túl TEE során igazolható óriás JPF-aneurizma megléte is [11], melynek diagnózisában a kontrasztanyag használata segítséget nyújthat [12].

A Doppler-echokardiográfia során a JPF-ben detektálható ejekciós sebességek a BPF-hez hasonlóan csökken-

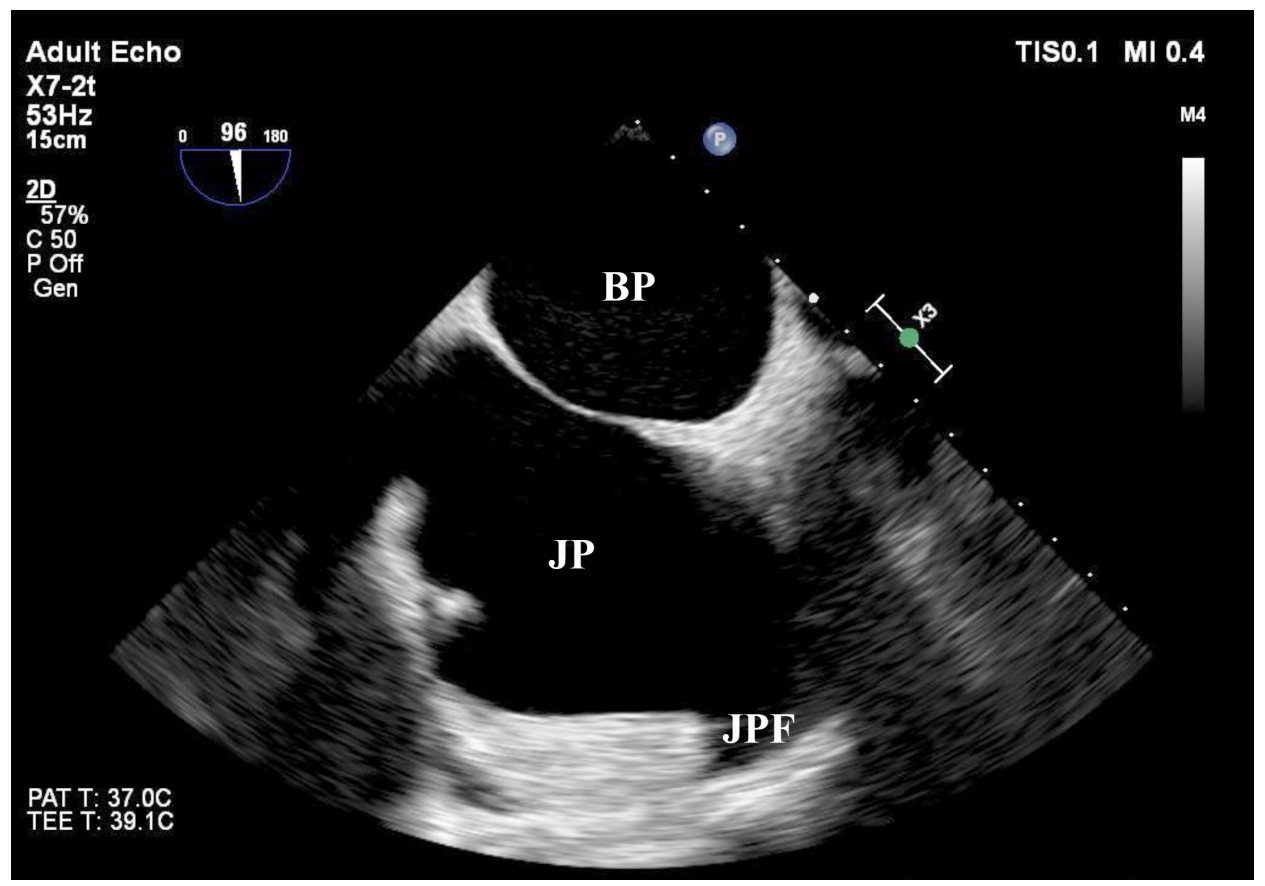

1. ábra

A jobb pitvari fülcse ábrázolása transoesophagealis echokardiográfia során

$\mathrm{BP}=$ bal pitvar; $\mathrm{JP}=$ jobb pitvar; $\mathrm{JPF}=$ jobb pitvari fülcse 


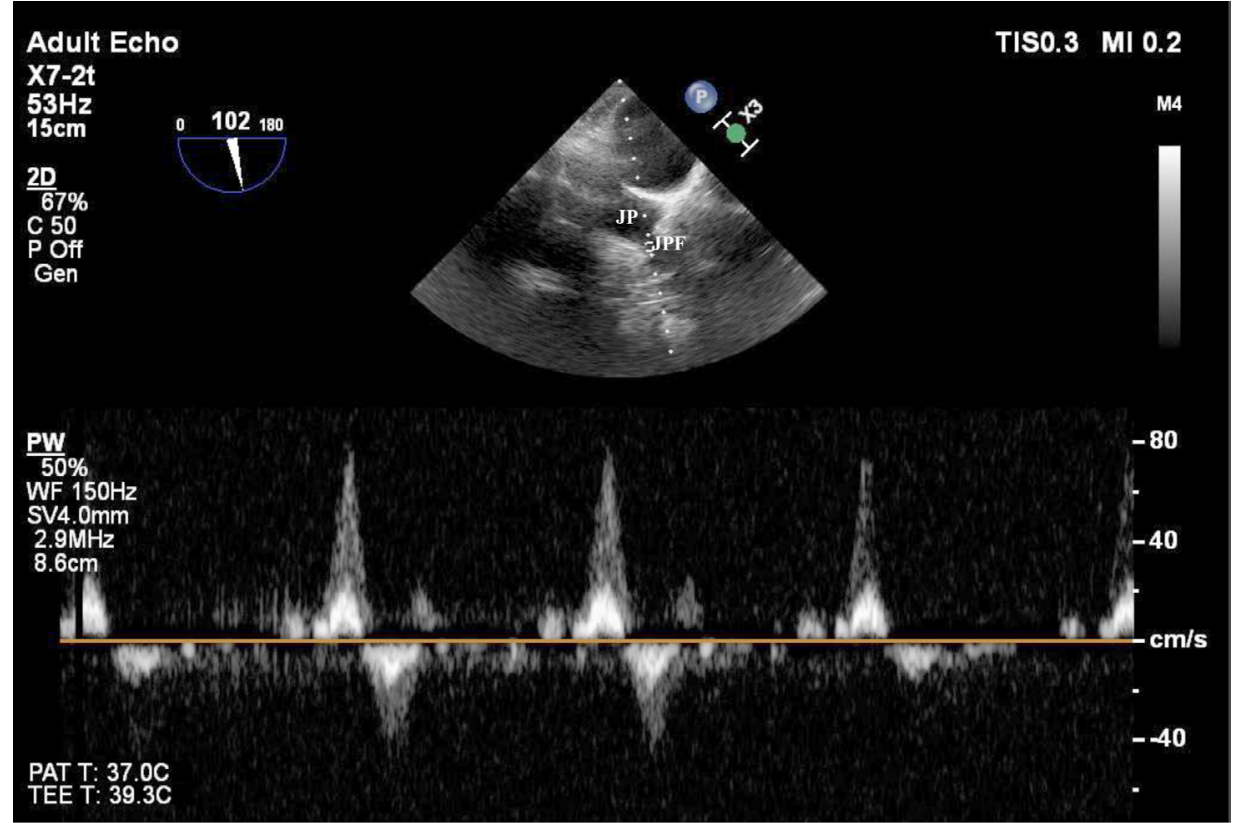

2. ábra A jobb pivari fülcse orificiumánál Dopplerrel mérhető áramlási sebesség
$\mathrm{JP}=$ jobb pitvar; JPF = jobb pitvari fülcse

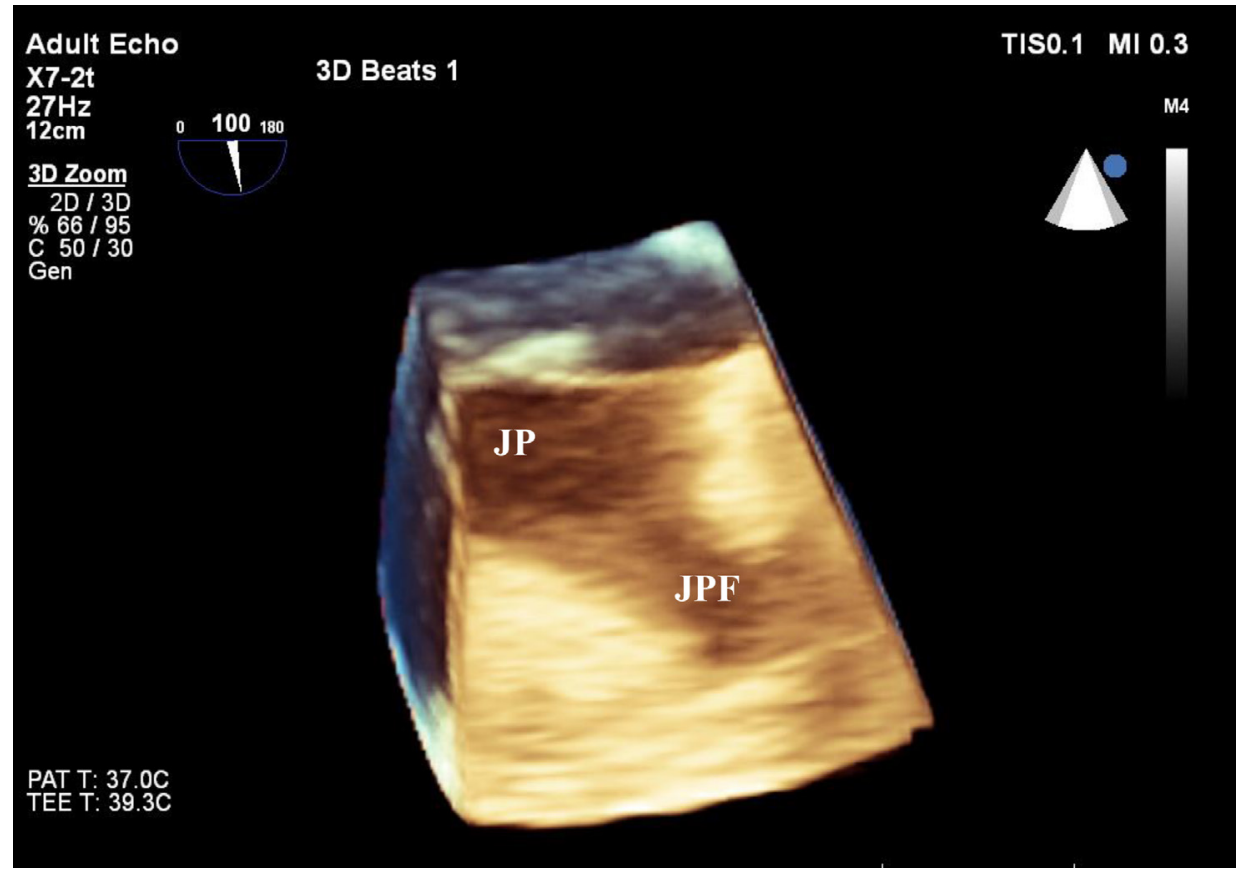

3. ábra $\mid \begin{aligned} & \text { Háromdimenziós transoesophagealis echokardiográfia során ábrázolható a jobb pitvari fülcse } \\ & \mathrm{JP}=\text { jobb pitvar; JPF = jobb pitvari fülcse }\end{aligned}$

tek PF fennállása esetén SR-hez képest $[10,13\rfloor$ (2. ábra). JPF-thrombus fennállása esetén a JPF-ben mérhető áramlási sebesség kevesebb volt, mint $25 \mathrm{~cm} / \mathrm{s}$ [10]. Bizonyos szerzők szerint a JPF-diszfunkció leginformatívabb markere az áramlási sebességek és a fali mozgások sebességének csökkenése [14].

Amikor szöveti Doppler-echokardiográfia segítségével (tissue Doppler imaging, TDI) a JPF medialis és lateralis falainak mozgását vizsgálták, PF fennállása esetén csökkent értékeket tudtak mérni [10]. JPF-thrombus meglétekor a JPF-fali mozgás sebessége $<6 \mathrm{~cm} / \mathrm{s}$-nak bizonyult [10].

$\mathrm{Az}$ újabb speckle-tracking (strain) és/vagy háromdimenziós echokardiográfiás eljárásokkal és azok klinikai jelentőségével kapcsolatos vizsgálati eredmények a JPF-vel nem érhetők el (3. ábra). 


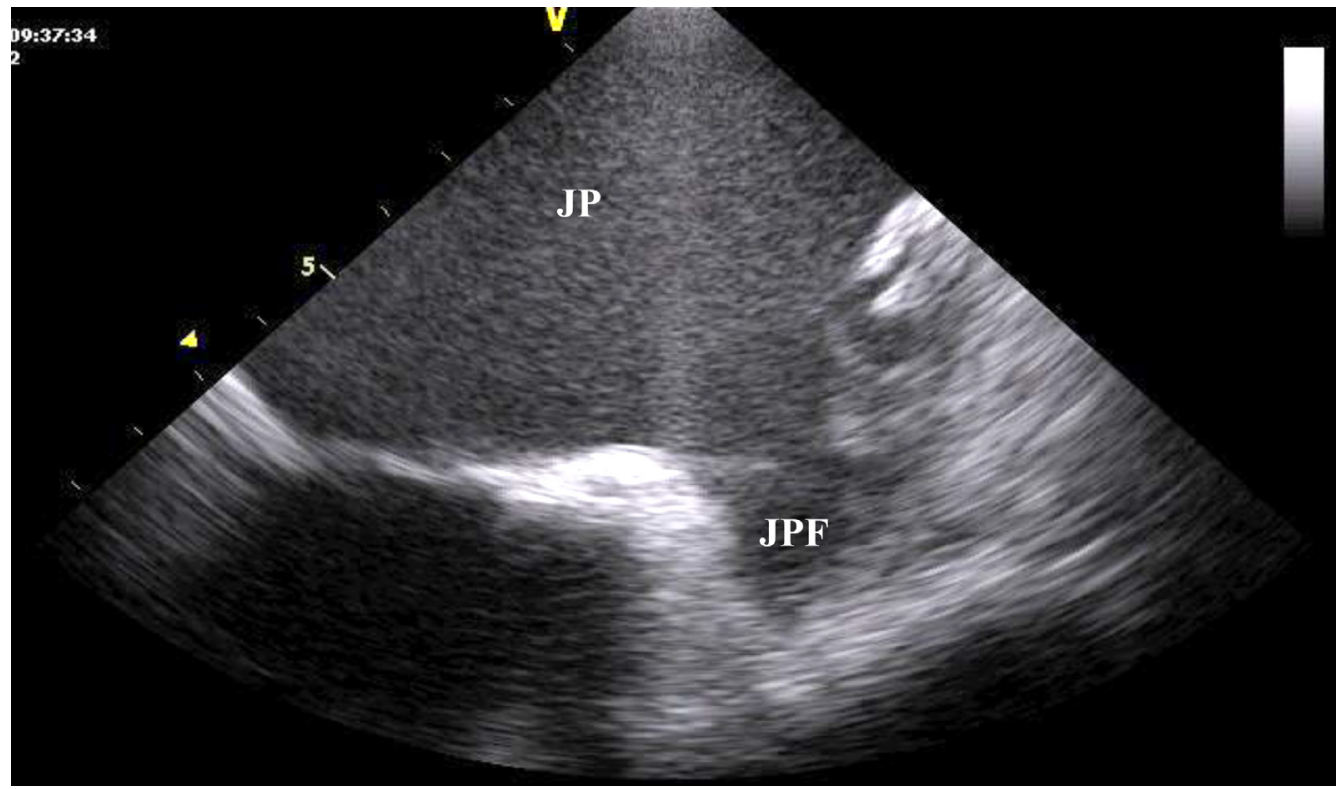

4. ábra

$\mid \begin{aligned} & \text { A jobb pitvari fülcse ábrázolása intracardialis echokardiográfia segítségével } \\ & \mathrm{JP}=\text { jobb pitvar; JPF = jobb pitvari fülcse }\end{aligned}$

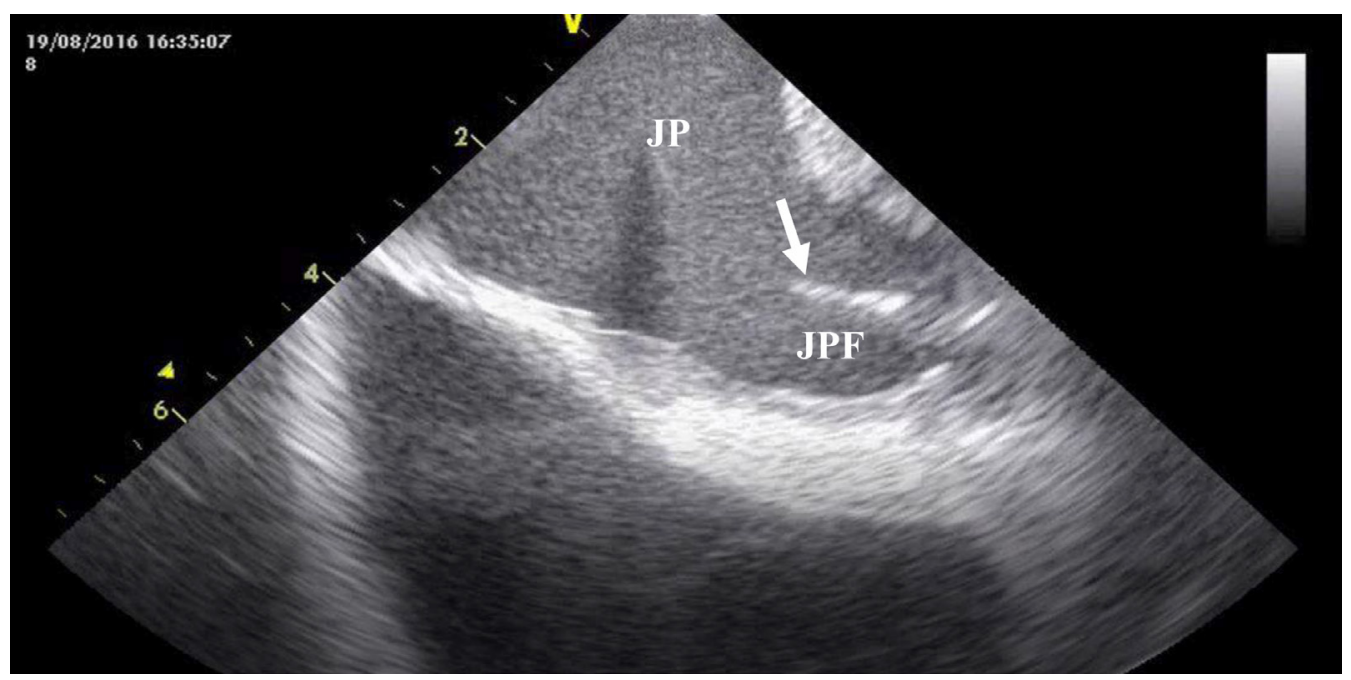

5. ábra

Pitvari pacemakerelektróda ábrázolása intracardialis echokardiográfia során a jobb pitvari fülcsében

$\mathrm{JP}=$ jobb pitvar; JPF $=$ jobb pitvari fülcse

\section{Transthoracalis echokardiográfia (TTE)}

A JPF vizualizálása TTE során rutinszerűen nem alkalmazott diagnosztikus eljárás, irodalmi adatok azonban leírtak TTE során detektálható aneurizmatikus eltéréseket $[3]$.

\section{Intracardialis echokardiográfia (ICE)}

ICE során az ultrahangkatétert a vena cava inferior szájadéka fölé vezetjük, majd a transzducert annak anterior és balra történő pozicionálásával a JP, a jobb kamra és a tricuspidalis billentyü hozható látótérbe. Ilyenkor a JPF síkját a transzducer anterolateralis, az óramutató járásával ellentétes rotációjával érhetjük el (4. ábra). Irodalmi adatok alapján tudjuk, hogy az ICE-képalkotásos katéterablatiós beavatkozás során a TEE a JPF ábrázolásának alternatívája [15]. A JPF intracardialis ultrahanggal történő vizualizálására elektrofiziológiai beavatkozások során, speciális esetekben, vagy a fülcsére lokalizált pitvari tachycardia rádiófrekvenciás ablatiója során lehet szükség. Speciális esetekben (lead perforáció gyanú, pitvari pacemakerelektróda extrakciója) pitvari pacemakerelektróda lokalizációjának ellenőrzésére is alkalmas lehet (5. ábra). 


\section{Következtetés}

PF fennállása esetén a thrombusképződés emelkedett rizikójával kell számolni, mely a szív jobb felét is érintheti. PF kivizsgálása során sajnos a napi rutin a BP és a BPF vizsgálatára korlátozódik, annak ellenére, hogy a fent részletezett irodalmi adatok alapján az esetek egy részében a JP/JPF-ben is észlelhető SEC vagy thrombusképződés. Ennek megfelelően a JPF vizsgálata nagyobb odafigyelést kívánna a klinikai gyakorlatban.

Anyagi támogatás: A közlemény megírása anyagi támogatásban nem részesült.

Szerzői munkamegosztás: N. A., S. L., F. T.: A kézirat megírása. H. K., K. M.: Az ábrák elkészítése.

Érdekeltségek: A szerzőknek nincsenek érdekeltségeik.

\section{Irodalom}

[1] McAlpine WA. Heart and coronary arteries. An anatomical atlas for clinical disgnosis, radiological investigation, and surgical treatment. Springer Verlag, New York, NY, 1975.

[2] Ozer O, Sari I, Davutoglu V. Right atrial appendage: forgotten part of the heart in atrial fibrillation. Clin Appl Thromb Hemost. 2010; 16: 218-220

[3] Yoon JW, Kim HJ, Lee SH, et al. A case of right atrial aneurysm incidentally found in old age. J Cardiovasc Ultrasound. 2009 17: 96-98.

[4] Flachskampf FA, Badano L, Daniel WG, et al; European Association of Echocardiography; Echo Committee of the European Association of Cardiothoracic Anaesthesiologists, Roelandt JR, Piérard L. Recommendations for transoesophageal echocardiography: update 2010. Eur J Echocardiogr. 2010; 11: 557-576.

[5] Bashir M, Asher CR, Garcia MJ, et al. Right atrial spontaneous echo contrast and thrombi in atrial fibrillation: a transesophageal echocardiography study. J Am Soc Echocardiogr. 2001; 14: $122-127$.
[6] de Divitiis M, Omran H, Rabahieh R, et al. Right atrial appendage thrombosis in atrial fibrillation: its frequency and its clinical predictors. Am J Cardiol. 1999; 84: 1023-1028.

[7] Subramaniam B, Riley MF, Panzica PJ, et al. Transesophageal echocardiographic assessment of right atrial appendage anatomy and function: comparison with the left atrial appendage and implications for local thrombus formation. J Am Soc Echocardiogr. 2006; 19: 429-433.

[8] Lohvinov YM, Mikhaliev KO, Zharinov OJ. Contemporary echocardiographic assessment of atrial appendages in non-valvular atrial fibrillation. Kardiol Pol. 2015; 73: 701-710.

[9] Piszko P, Lewczuk J, Lenartowska L, et al. Pulmonary thromboembolism in 102 consecutive patients with chronic atrial fibrillation. Diagnostic value of echocardiography. Kardiol Pol. 2007; 65: 246-251.

[10] Sahin T, Ural D, Kilic T, et al. Right atrial appendage function in different etiologies of permanent atrial fibrillation: a transesophageal echocardiography and tissue Doppler imaging study. Echocardiography 2010; 27: 384-393.

[11] Toufan M, Pourafkari L, Akbarzadeh F, et al. A case of right atrial appendage aneurysm mimicking a pericardial cyst on echocardiogram. Echo Res Pract. 2014; 1: K5-K8.

[12] Cianciulli TF, Rubinetti ER, Saccheri MC, et al. Contrast echocardiography in the non-invasive diagnosis of giant aneurysm of the right atrial appendage. Eur J Echocardiogr. 2010; 11: E26.

[13] Nemes A, Havasi K, Ambrus N, et al. Echocardiographic assessment of the left atrial appendage - transoesophageal, transthoracic and intracardiac approaches. [A bal pitvari fülcse echokardiográfiás vizsgálata - transoesophagealis, transthoracalis és intracardialis lehetőségek.] Orv Hetil. 2018; 159: 335-345. [Hungarian]

[14] Lohvinov Y, Zharinov O, Mikhalieb K, et al. Right atrial appendage structure and function in non-valvular atrial fibrillation. Eur Heart J. 2014; 35 (abstract suppl. 1): 628.

[15] Anter E, Silverstein J, Tschabrunn CM, et al. Comparison of intracardiac echocardiography and transesophageal echocardiography for imaging of the right and left atrial appendages. Heart Rhythm 2014; 11: 1890-1897.

(Nemes Attila dr., Szeged, Semmelweis u. 8., 6725 e-mail: nemes.attila@med.u-szeged.hu)

\section{"Nullus agenti dies longus est." (Seneca) (A tevékeny ember számára egy nap se hosszú.)}

A cikk a Creative Commons Attribution 4.0 International License (https://creativecommons.org/licenses/by/4.0/) feltételei szerint publikált Open Access közlemény, melynek szellemében a cikk bármilyen médiumban szabadon felhasználható, megosztható és újraközölhető, feltéve, hogy az eredeti szerző és a közlés helye, illetve a CC License linkje és az esetlegesen végrehajtott módosítások feltüntetésre kerülnek. (SID_1) 